\title{
Increased interest and concentration of student learning with using the kotak pas
}

\author{
Doni Aldo Siahaan ${ }^{1 *}$, Putri Khairiah Nasution ${ }^{2}$, Lukman Hakim ${ }^{3}$ \\ ${ }^{1}$ Departement of Biology, Mathematics and Natural Science Faculty, Universitas Sumatera \\ Utara \\ ${ }^{2}$ Departement of Mathematics, Matematics and Natural Science Faculty, Universitas \\ Sumatera Utara \\ ${ }^{3}$ Departement of Physics, Matematics and Natural Science Faculty, Universitas Sumatera \\ Utara \\ *Email: donialdo77@gmail.com
}

\begin{abstract}
The learning model is one of the important parts in the world of education. Learning models with the involvement of play can help students understand mathematic and science. One method of play that can be used by elementary students is the Kotak Pas. Kotak Pas is a learning media that is easy to use, easy to carry or move to place. Kotak Pas is equipped with ten game books that contain mathematic and science. Each book has levels, from the easiest to the most difficult. Community service activities are carried out with several methods, namely conducting surveys and designing teaching materials, introducing Fitting Boxes, training teachers and students with Kotak Pas, and feedback.
\end{abstract}

Keywords: Teaching Aids, Kotak Pas, learning media

\begin{abstract}
Abstrak
Model pembelajaran merupakan salah satu bagian penting dalam dunia pendidikan. Model pembelajaran dengan melibatkan ativitas bermain dapat membantu siswa dalam memahami materi matematika dan sains. Salah satu metode permainan yang dapat digunakan oleh siswa/i tingkat sekolah dasar yaitu Kotak Pas. Kotak Pas merupakan media pembelajaran yang mudah digunakan, mudah dibawa atau dipindah tempatkan. Kotak Pas dilengkapi dengan sepuluh buku permainan yang berisikan materi matematika dan sains. Setiap buku mempunyai tingkatan-tingkatan, dari yang termudah hingga tersulit. Kegiatan pengabdian kepada masyarakat ini dilakukan dengan beberapa metode yaitu melakukan survey dan perancangan bahan ajar, pengenalan Kotak Pas, pelatihan guru dan siswa dengan Kotak Pas, serta umpan balik.
\end{abstract}

Kata Kunci : Alat Peraga, Kotak Pas, media pembelajaran

\section{PENDAhULUAN}

Perkembangan teknologi dewasa ini telah mewarnai perkembangan dunia pendidikan. Teristimewa, bidang matematika dan sains. Dikatakan demikian, disebabkan betapa mudahnya membuat alat peraga matematika dan sains. Alat peraga merupakan instrumen yang bertujuan untuk menghubungkan pemahaman satu pengguna dengan pengguna lainnya. Pengguna tersebut kemudian dapat memanfaatkannya melalui fasilitas dalam metodologi pembelajaran. Salah satu alat peraga matematika dan sains yang sekarang umum digunakan adalah kotak pas.

Sebelum proses belajar mengajar berlangsung, guru diharuskan memiliki model pembelajaran. Dalam model tersebut terdapat media yang digunakan dan harus sesuai dengan materi ajar, supaya tujuan pembelajaran dapat tercapai dengan baik. Dalam proses belajar 
mengajar di kelas terdapat keterkaitan yang erat antara guru, siswa, kurikulum, sarana dan prasarana. Guru mempunyai tugas untuk memilih model dan media pembelajaran yang tepat sesuai dengan materi yang disampaikan demi tercapainya tujuan pendidikan. Alat peraga terkadang membutuhkan banyak biaya baik dari segi uang, waktu, ataupun tenaga. Tingginya biaya untuk menyediakan alat peraga matematika dan sains sering kali menyebabkan menurunnya kualitas dan kuantitas alat tersebut. Hal ini berdampak pada menurunnya konsentrasi dan minat belajar, baik guru maupun siswa.

Alat peraga matematika dan sains tidak secara spesifik ditujukan oleh institusi. Padahal, banyak sekolah yang memanfaatkan aplikasi alat peraga matematika dan sains untuk meningkatkan efisiensi dan konsentrasi proses belajar mengajar. Pemanfaatan alat peraga, yaitu kotak pas secara maksimal, baik secara kuantitas maupun kualitas, telah terbukti dapat membantu sekolah untuk melakukan transfer of knowledge dengan biaya yang jauh lebih rendah dengan konsentrasi dan minat belajar yang lebih baik lagi. Kotak pas dirancang guna membantu siswa meningkatkan pemahaman perhitungan dasar matematika melalui pemasangan perangkat kotak pas saat menjawab soal. Selain itu, kotak pas dapat meningkatkan memori siswa dalam mengingat materi ilmu pengetahuan alam, serta memotifasi siswa untuk belajar melalui teknik permainan. Kotak pas yang mudah dibawa dan dipindah-pindahkan dapat membantu guru menggunakan perangkat ini lebih efektif dan efesien.

Permasalahan yang dihadapi oleh guru-guru SD Swasta Mulia Medan (Mitra) dan SD Swasta Taman Siswa dalam program Pengabdaian Masyarakat ini adalah sebagai berikut:

1. Minimnya minat siswa sekolah dasar untuk mempelajari ilmu pengetahuan alam dan matematika. Salah satu penyebabnya adalah minimnya ketersediaan alat peraga belajar

2. Butuh upaya yang besar untuk meningkatkan konsentrasi belajar siswa saat mengikuti proses pembelajaran ilmu pengetahuan alam dan matematika

3. Selama ini siswa sekolah dasar hanya mempelajari konsep teori, tetapi belum melibatkan aktivitas motorik untuk lebih meningkatkan pemahaman belajarnya.

Pada pelaksanaan pengabdian masyarakat ini, tim pelaksana memilih SD Swasta Taman Siswa dan SD Swasta Mulia Medan sebagai tempat pengabdian. SD Swasta Taman Siswa merupakan sebuah SD yang terletak di Jln. Setia Budi Pasar 1 kelurahan Tanjung Kecamatan Medan Selayang. Sekolah ini memiliki sekitar 94 siswa yang terbagi dalam 6 kelas. Dengan jumlah siswa yang cukup banyak, maka distribusi Proses Belajar Mengajar secara efisien dan efektif menjadi masalah yang sulit dipecahkan tanpa bantuan Alat Peraga Matematika. Begitu juga dengan SD Swasta Mulia yang terletak di Jln. Kenanga Raya no. 33 Kelurahan Tanjung Sari

Kecamatan Medan Selayang. Dengan jumlah siswa/i yang mencapai 230 orang, media distribusi proses belajar mengajar yang efektif juga menjadi permasalahan bagi pihak sekolah. Saat ini, kedua sekolah tersebut belum memiliki fasilitas dan prosedur standar dalam memanfaatkan alat peraga sebagai salah satu sarana proses belajar mengajar kepada siswa/i dan guru.

\section{METODE PELAKSANAAN}

Adapun proses pelaksanaan kegiatan pengabdian masyarakat ini dapat dibagi menjadi tahap-tahap sebagai berikut:

1. Studi Awal.

Pada tahap ini, tim pelaksana akan melakukan survey ke kedua sekolah (mitra) untuk mengetahui kebutuhan yang dimiliki oleh setiap sekolah untuk mendukung kegiatan proses belajar mengajar sains dan matematika melalui alat peraga. Data ini akan digunakan dalam proses pengadaan fasilitas pendukung dan perancangan bahan ajar.

2. Pengenalan Fasilitas.

Tim pelaksana bersama pihak sekolah (mitra) akan melakukan sosialisasi fasilitas yang akan digunakan untuk mendukung proses pembelajaran sains dan matematika via metode pembelajaran permainan menggunakan kotak pas.

3. Pelatihan Guru Sekolah dan Siswa. 
Tim Pelaksana akan melakukan pelatihan kepada siswa-siswi sekolah dasar (mitra) dan pengajar (guru) tentang metoda dan pemanfaatan alat kotak pas sebagai metode pembelajaran sains dan matematika

4. Umpan Balik.

Tim Pelaksana akan mengumpulkan masukan dari pihak sekolah (mitra) tentang pengalaman dan perubahan setelah implementasi metode pembelajaran via alat kotak pas berhasil dilakukan. Selain itu, tim pelaksana juga akan mengambil survey dari siswa/i dan guru sebagai target dari penyebaran informasi tersebut.

\section{HASIL DAN PEMBAHASAN}

Tujuan penggunaan kotak pas adalah membantu siswa dalam hal meningkatkan pemahaman perhitungan dasar matematika, pengenalan dasar sains, dan bahasa inggris melalui pemasangan perangkat kotak pas saat menjawab soal. Selain itu, kotak pas dapat meningkatkan memori siswa dalam mengingat materi ilmu pengetahuan alam, serta memotifasi siswa untuk belajar melalui teknik permainan. Pada kegiatan pengabdian ini, terlebih dahulu kita melakukan observasi permasalahan yang terdapat pada masing-masing mitra terkait dengan kebutuhan model pembelajaran berikut media yang tepat sesuai dengan materi yang disampaikan demi tercapainya tujuan pembelajaran di sekolah dasar. SD Swasta Taman Siswa dan SD Swasta Mulia Medan memiliki beberapa media belajar, namun belum memiliki kotak pas yang dapat merangsang belajar dan ingatan siswa melalui metode permainan.

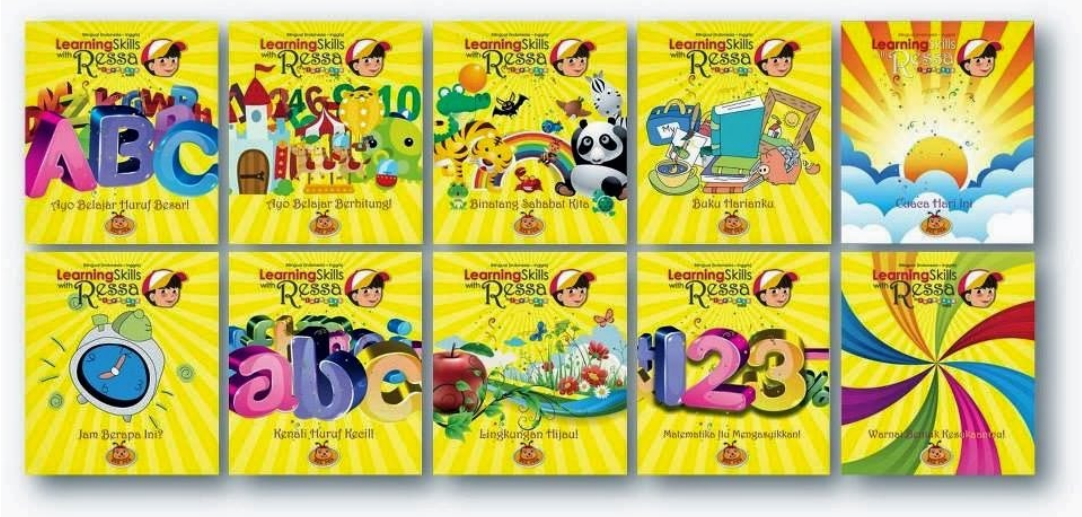

Gambar 3.1 10 Buku Pendamping Kotak Pas

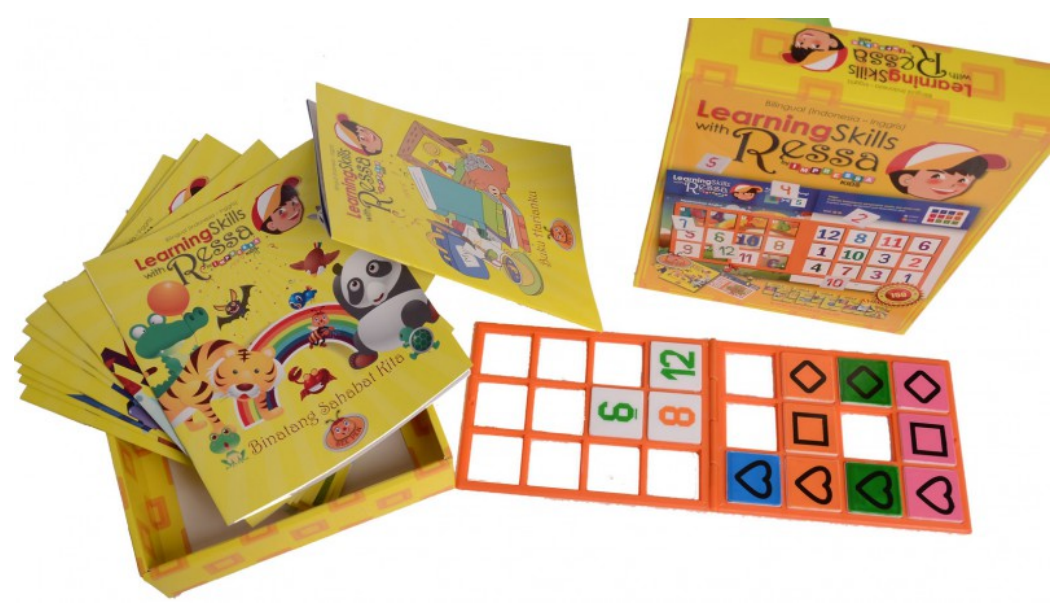

Gambar 3.2 Kotak Pas 


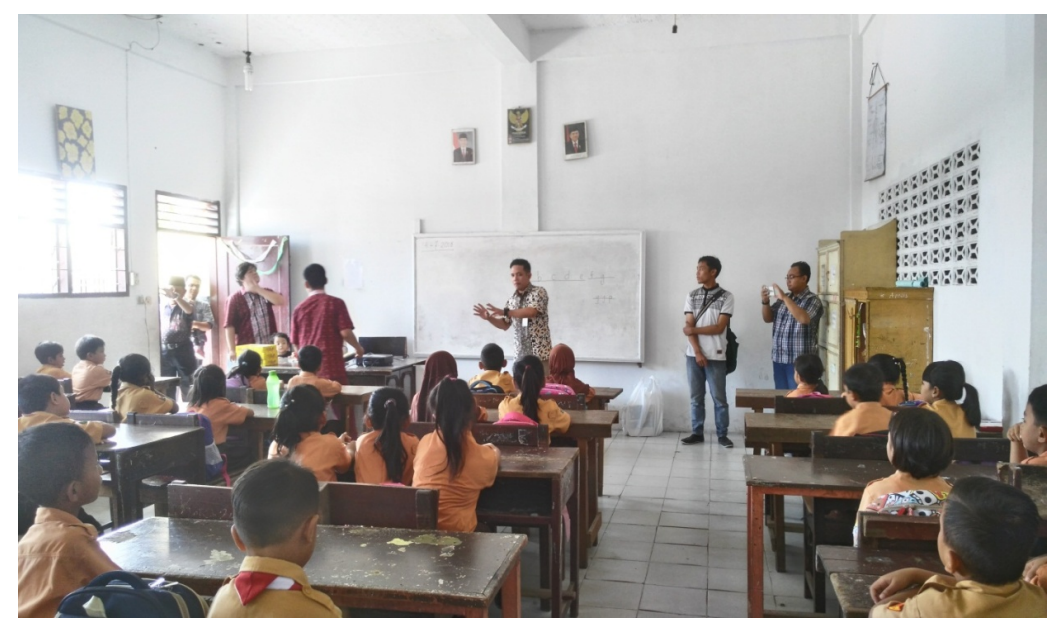

Gambar 3.3 Tim Pengabdian Masyarakat USU sedang Memberi Pengarahan dan Motivasi Belajar kepada Siswa Siswi SD Taman Siswa.

Tim Pengabdian masyarakat selanjutnya memperkenalkan alat kotak pas melalui slide yang ditayangkan dan dilisankan petunjuk penggunaannya dari awal kemudian mendemonstrasikan penggunaan alat itu di hadapan siswa didampingi guru kelas SD Taman Siswa.

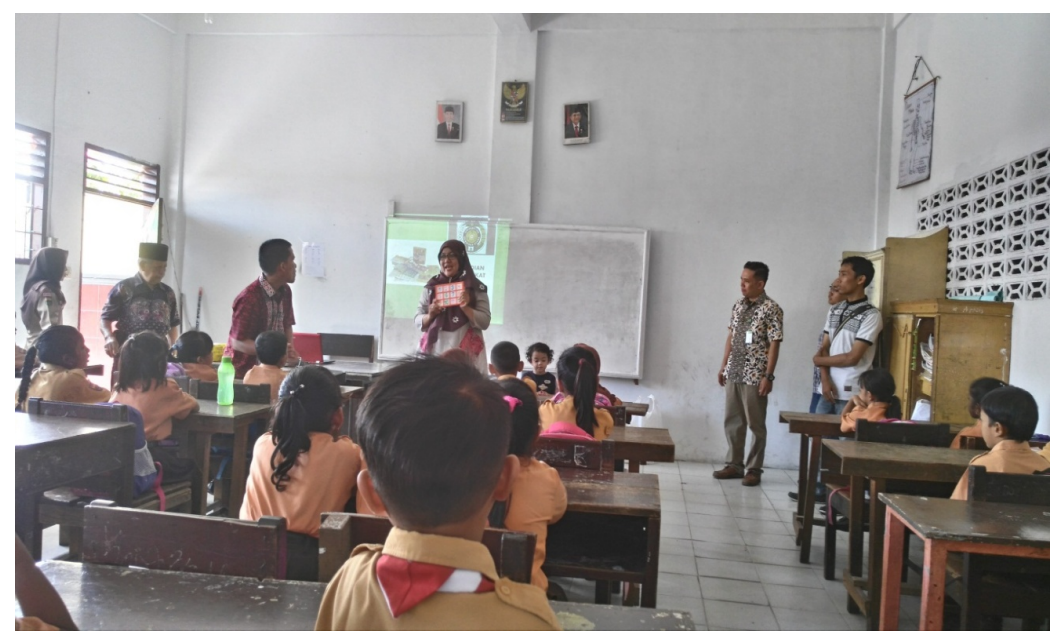

Gambar 3.4 Salah Satu Tim Pengabdian Masyarakat USU sedang Menjelaskan Petunjuk Penggunaan dan Demonstrasi Kotak Pas kepada Siswa Siswi SD Taman Siswa

Siswa SD Taman Siswa diundang untuk mencoba sendiri penggunaan kotak pas dengan memulai mencocokan kotak angka yang dipilih dengan keterangan gambar dibawahnya yang akan dipasangkan dengan gambar yang sesuai di halaman berikutnya dari buku pendamping kotak pas tersebut. Tim pengabdian masyarakat akan memandu pengunaan kotak tersebut bersama siswa dan mengulangi penggunaannya kepada siswa, agar masing-masing siswa semakin mahir dan menyenangi pembelajaran menggunakan media kotak pas ini. Guru pendamping juga diundang untuk mengamati penggunaan kotak pas ini dan mengarahkan siswa-siswi mereka untuk menyimak dan mencoba perlahan-lahan kotak pas. Siswa-siswi SD Taman siswa mencoba sendiri secara bergantian penggunaan kotak pas bersama teman-teman mereka dengan semangat mereka menikmati proses belajar sambil bermain. 


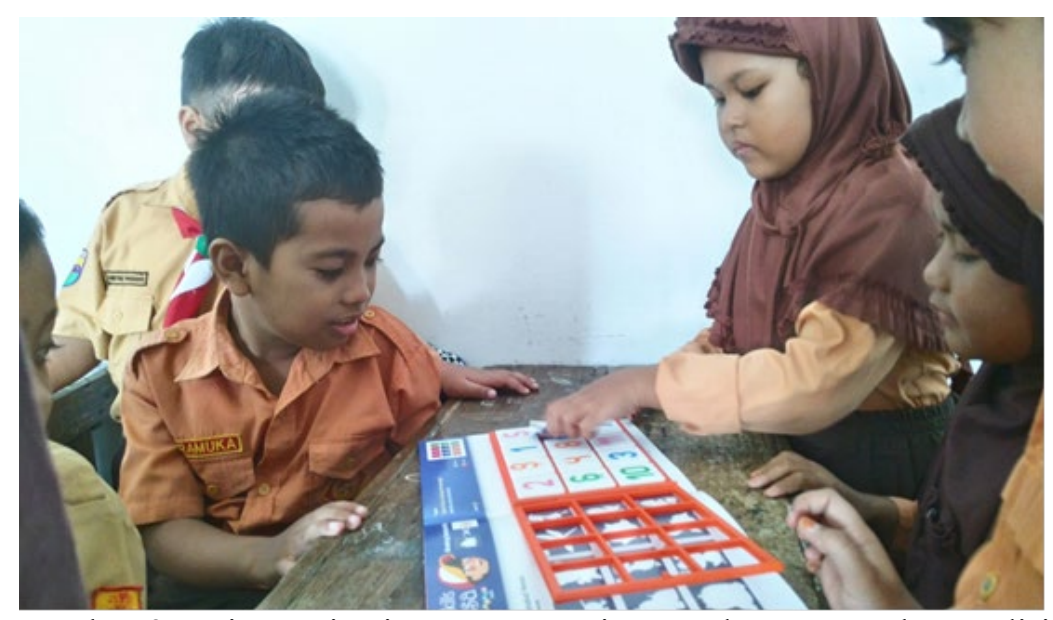

Gambar 3.5 Siswa Siswi SD Taman Siswa sedang mencoba sendiri menggunakan kotak pas

Kegiatan pengabdian yang sama juga dilakukan di sekolah kedua yakni SD Mulia Medan.

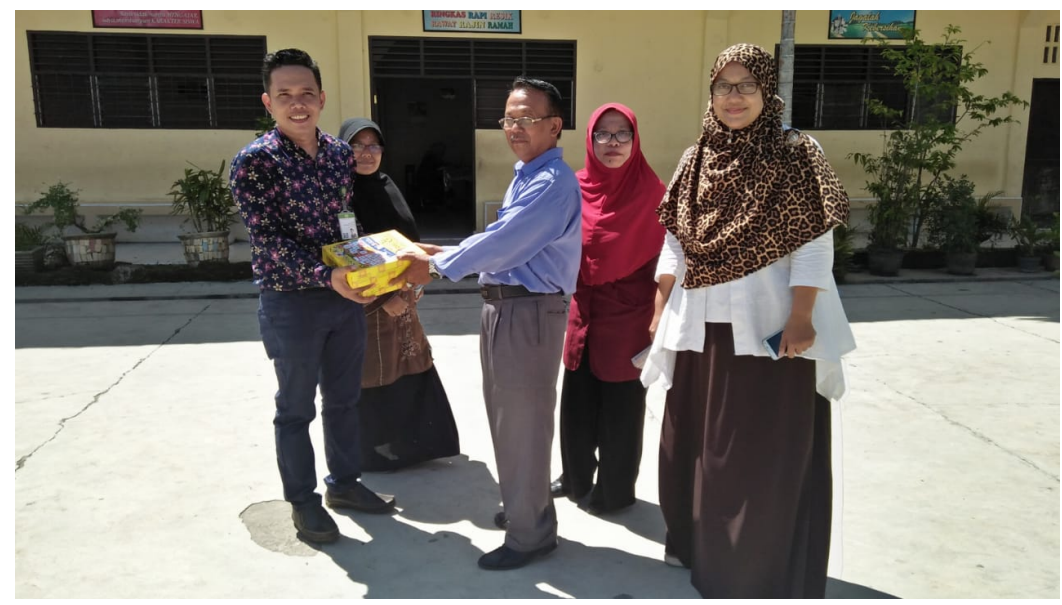

Gambar 3.6 Tim Pengabdian Masyarakat USU Melakukan Penyerahan Kotak Pas kepada Pihak Sekolah yang Diterima Langsung oleh Bapak Kepala Sekolah SD Mulia

Sebulan kemudian, Tim Pengabdian kembali ke sekolah mitra untuk melaksanakan umpan balik.

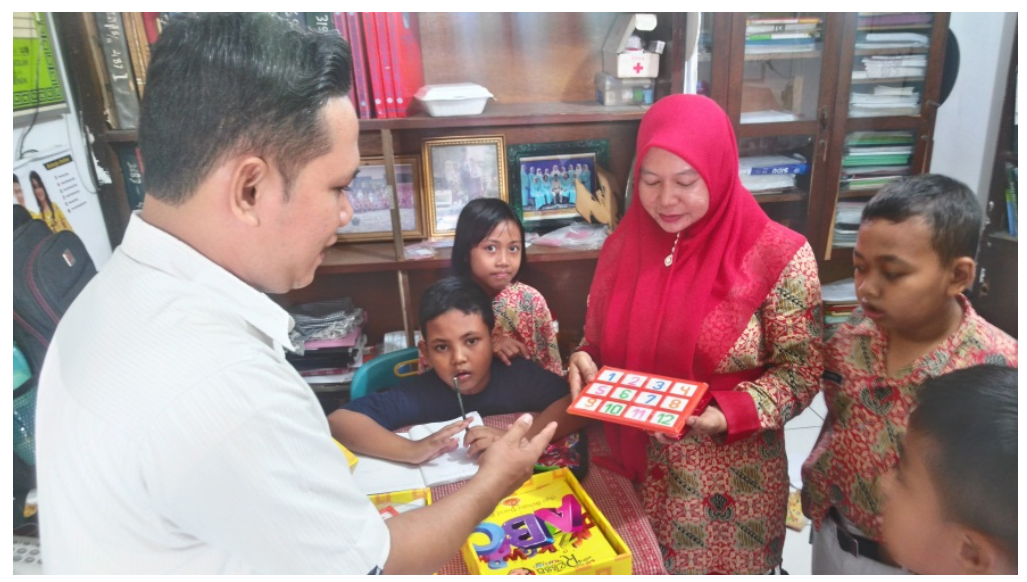

Gambar 3.7 Tim Pengabdian Masyarakat Melakukan Proses Umpan Balik 


\section{KESIMPULAN}

Adapun kesimpulan yang diperoleh dari kegiatan pengabdian masyarakat di SDIT Deli Insani yaitu:

1. Kegiatan pengabdian masyarakat yang telah dilakukan mendapatkan respon yang luar biasa dari siswa, guru, kepala sekolah serta orang tua siswa karena selain mendapatkan bantuan media pembelajaran berupa kotak pas, siswa juga senang mendapatkan kunjungan dari para Tenaga Pengajar Program Studi Matematika, FMIPA, USU.

2. Terjadi peningkatan kemampuan pelajaran matematika dan sains para siswa dan guru sebagai objek dari pengabdian masyarakat ini.

3. Guru mempunyai media pembelajaran yang dapat digunakan dalam pengajaran.

\section{UCAPAN TERIMAKASIH}

Artikel ini merupakan salah satu hasil dari Program Pengabdian kepada Masyarakat yang Dibiayai oleh dana NON PNBP Universitas Sumatera Utara Sesuai dengan Surat Perjanjian Penugasan Pelaksanaan Pengabdian kepada Masyarakat Program Mono Tahun (IbM) Dosen Muda (Batch 2) No. 1077/UN5.2.3.2.1/PPM/2018. Oleh karena itu, diucapkan terima kasih kepada Rektor Universitas Sumatera Utara atas dukungan dana dan fasilitas yang diberikan. Terima kasih juga kepada Mitra pada kegiatan pengabdian ini.

\section{DAFTAR PUSTAKA}

Anita Lie (Herdian, S.Pd). Fungsi dan Prinsip Model Make-A Match (Online) (http://herdy07.wordpress.com/2009/04/29 ) Dimyati, dkk, 2006, Belajar dan Pembelajaran, Jakarta:

Rineka Cipta. Gagne. ( The Conditions of Learning. 1977). Pengertian Belajar (Online) (http://belajarpsikologi.com/pengertian-belajar-menurut-ahli/)

Hamalik. (1994:116). Fungsi dan Prinsip Model Make-A Match(Online) ( http://Tarmizi.Wordpress.Com/2008/12/03/pembelajaran-kooperatif-make-amatch) Lie. (2003:30). Pengertian Model Make-A Match(Online)

( http://Tarmizi.Wordpress.com/2008/12/03/pembelajaran-kooperatif-make-a match/ ) Lie. (2003:30). 